\title{
Islamizing Conventional Banking: Shari’a Compliance Challenges in Islamic Branch Banking
}

\author{
Jalal Dawar ${ }^{1}$ \\ Shakir Ullah ${ }^{2}$
}

\begin{abstract}
Despite the vast research by scholars in the arena of Islamic banking, little is known about the rivalry between the management and Shari'ah scholars in attaining their objectives of profitability and Shari'ah compliance respectively. The managers look for financial value generation and the Religious Scholars guides and monitor them within the ambit of Shari'ah principles. Apparently, this collaboration of Managers and Religious Scholars sounds alright, but after a thorough investigation, it appears that both the parties' endeavors are different, rather opposite objectives. The purpose of this study is to investigate this vying of objectives in the advances departments of Islamic banks, using grounded theory methodology. With a motive to dissect this grapple of objectives in the advances departments of Islamic banks, data was collected from the employees and the customers of different Islamic banks through repeated interviews. The finding divulged that the tension between the two very important pillars of Islamic banks, i.e. the managers and the Shari'ah scholars can be clinched by lowering pressure on managers, enhancing employees training and development, ensuring frequent Shari'ah audits, increasing the number of Shari'ah auditors, and customers' awareness. This paper also concludes, in defiance of such measures, that each pillar of the Islamic bank will manage to wangle their ways into achieving their corresponding objectives. Consequently, the Managers may attempt to increase profits at the cost of Shari'ah compliance while the Shari'ah scholars may push for Shari'ah compliance at the expense of profitability.
\end{abstract}

Keywords: Shari'ah objectives, Islamic banking, Fatwa, Shari'ah compliance, Managers, Shari'ah scholars

\section{Introduction}

\footnotetext{
Jalal Dawar is working as Planning Officer at the Home Department, Government of Khyber Pukhtunkhwa, Pakistan

2 Assistant Professor at the Institute of Management Sciences, Peshawar, Pakistan. He can be reached at shakir_fla@hotmail.com
} 
Islamic banking is an emerging phenomenon that conforms to the injunctions of Islam or Islamic law, for which the technical term to quote is "Shari'ah." Islamic way of banking has attracted an untapped niche market. These banks operate under the umbrella of Shari'ah and are expected to follow Shari'ah in letter and spirit. Islamic Financial institutions obtain their guidance from well-reputed scholars of Shari'ah while the implementation of these guidelines is carried out by managers having profound experience in banking. Islamic banks are in fact, profit-making entities within the boundaries of Shari'ah. The managers in banks look after value generation, and the Religious Scholars guides and monitors them within the ambit of Shari'ah compliance.

Apparently, the collaboration of Managers and Religious Scholars sounds alright, but after a thorough investigation, it appears that both the parties' endeavors are different, rather opposite objectives. The managers to pursue with the aim of value maximization are not free to do whatever it takes. Shari'ah Scholars monitor them and guides them in attaining their goal to maximize value in a Shari'ah-compliant manner. This situation, seemingly, gives rise to a conflict of objectives because the managers may attempt to increase profits at the cost of Shari'ah compliance while the Shari'ah scholars may push for Shari'ah compliance at the expense of profitability.

The purpose of this study is to investigate this conflict of objectives in the context of advances departments of Islamic banks, using grounded theory methodology. Barney Glaser and Anselm Strauss were the two scholars who initially developed Grounded theory in 1967. They were not in harmony with the trend in which existing approaches dominated sociological research. They demonstrated that researchers lacked a method that would allow them to move from data to the opinions so that new approaches could develop. Such theories would be distinct to the circumstances in which they had been produced. They would be 'grounded' in the data from which they had arisen instead of relying on analytical constructs, sections or variables from the pre-extant method, Glaser, and Strauss, (1967). Grounded theory, therefore, was devised to open up capacity for the development of new, conceptualized theories. This theory is an in-depth investigation of a situation to know what is going on. It is a detailed iterative process based on the constant comparison of concepts arising from the data. It needs a high level of intuition and analytical sensitivity. First of all, interviews are conducted then transcribed. The transcription is read several times to identify essential links related to the situation. When the researcher read the transcriptions repeatedly, the process furthers to develop Open Codes. Then these Open Codes are converted into a high level of abstraction called Axial Codes. At this stage, the researcher gets a paradigm model. The next step is 
to generate the phenomena and explain all the causal conditions, strategies, and consequences to prepare Selective coding to identify the core category. At last, the results are discussed, and recommendations are given. The findings of this study revealed that there is a considerable compromise on Shari'ah compliance within the advances departments of Islamic banks. This compromise is concocted by the managers and customers alike.

\section{Preliminary Literature Review}

The origination of Islamic Law (Shari'ah) on how Muslims should administer their commercial and financial operations is as ancient as Islam itself. Though, the modernized history of Islamic banking can be ascertained back in the 1960s. It was not until the last decade that Islamic banking appeared as an established player in the financial arena. The Middle East and Malaysia remain the hub of Islamic finance, albeit most notable development is the emergence of non-Muslim countries as important centers of Islamic banking and finance.

Before the enlightenment of Islamic Banking, all the Muslim customers had to depend on the conventional banking practices. Those bank's products and services were not by the principles of Islam, as the traditional banking products revolve around the earning of interest (Riba) which is illegitimate in Islam. The globalization and economic call of countries collaborating with each other to advance the financial fabrications of their states had become unattainable without admitting the Secular banking system. These conventional banks, therefore, were acknowledged to place branches in different countries which concluded with giving origins to the trend of interest-based transactions and easy lending. This leads the Muslim nations to build and develop the financial institutions which would rely entirely on the Islamic philosophy. It got a little time to gain attention and determination of other countries of the world.

Islamic Law forbids to take or give interest on money lent or borrowed, which is usually called Riba, Iqbal and Molyneux, (2006). Islamic Law bans the giving or gaining of Riba, which is supposedly responsible for cutting off the natural relationships between people, strengthen injustice, and results in social anxiety, Ahmad, Rehman, and Saif, (2010). However, the entire Muslim Ummah is not in harmony that the Qur'an unambiguously states such prevention. Some Muslims say that the forbidding is merely intended to halt a particular pre-Islamic practice which resulted in the slavery of many people and hence other types of Riba are permitted, Kuran (2001) Although, the ban on Reba is the core principle of Islamic Banking to differentiate itself from Conventional Banking. Notwithstanding, the notable refutation of 
interest in Islamic finance is justified by an array of other stratagems which warrant that the purpose of profit is not endangered, and also mean that compliance with the high-minded social ideals, said to justify the refusal on interest is not a fundamental consideration Lee \& Ullah, (2008).

\section{Controversies that makes Islamic Banking Controversial}

It is an absolute reality that Islamic banking is a phenomenon that has driven the financial realm by storm. Its continued germination throughout universal financial meltdown has attracted even more interest in it. All the major nonMuslim countries of the world are competing against each other to become the hub of Islamic finance. However, there is not all well and good. Controversies and challenges co-occur with the unprecedented and inevitable popularity and growth of Shari'ah based banking and finance.

According to Ali, (2005) The fatwa is a religious ruling, announced or presented by a scholar on the resolutions of Islamic laws. A Fatwa is needed for cases where there is no explicit and candid guidance from Quran and Sunnah. Fatwa shopping refers to seeking opinion and rulings by Islamic Scholars on matters where there is the vagueness that a particular product or banking activity is in line with Shari'ahh or not. Fatwa resolves controversies and addresses key challenges faced by the Islamic Finance Industry.

All the Islamic Banks have their Shari'ah boards which oversee and verify conformity of the bank's practices with Shari'ah Law. These Shari'ah Boards usually consist of Shari' ah scholars who have well versed in Shari'ah education. But, due to the inadequate number of scholars who are well versed in both finance and religion, the Shari'ahh boards are overburdened, and the approval process becomes complicated, time consuming and unpredictable.

From this backdrop, fatwa shopping can be expressed as the system that lets the financial institutions to ask for a fatwa on financial product or contracts from the scholars whom they think will consider such product as Shari'ah Compliant and later confer them the fatwa Wilson, (1999). This is believed by Ahmad et al. (2010) to be similar to "forum shopping." In forum shopping, the client attempts to get their legitimate case heard in the court thought most like to provide the ruling in their favor without taking into consideration the rule of conflict of law. According to which the litigation should be heard by the jurisdiction that has the most ties with such disputes. 
Fatwa shopping is intimidation to Islamic Finance Industry because it works against the harmonization of fatwas. Such alignment is required to minimize complications and difficulties to decrease the expense of structuring Islamic financial products, thus rendering more people with access to such products Lawai, (1994). Moreover, fatwa shopping extends the inconsistency within Islamic financial products, leading consumers and investors to be dubious regarding the Shari'ah compliance of the offered products and deliberately leading them to lose faith in Islamic finance as a whole.

Conceivably associating to the issue of the fatwa, there is the issue of differences between interpretations of extant Shari'ah rulings. The existence of various sects in Islam and the truth that each faction has its authorization which provides guidance and understanding of Shari'ah concerns makes things more difficult. There is, therefore, invariably a likelihood that interpretations and explanation of a specific Shari'ah issues given by one sect's committee will diverge from the other sect's committee. These committees at times give contradictory rulings. A product approved by one committee can be refused by the other committee in the same command or jurisdiction. Diversity has also risen and exists between the countries and regions. For instance, Islamic financial confinements are much more lenient in Malaysia compared to the Middle East where the financial regulations have been implemented more rigorously. (SunGard 2008).

Another problem confronted by the Islamic Banking is the shortcoming of qualified personnel at all levels who know both the Conventional Banking \& the Islamic Banking alike. A person with the knowledge of traditional banking can easily understand the Islamic products. However, one cannot successfully develop and market the product without knowing the rules unique to Islam.

\section{Methodology}

Grounded theory is a strategy of inquiry in which researcher infers a general abstract method of a process, action or interaction rooted in the views of participants. This process comprises using multiple stages of data collection and the purification and interrelationship or categories of information (Channaz, 2006: Strauss and Corbin. 1990. 1998). Two prime characteristics of this design are the constant comparison of data with emerging categories and theoretical sampling of various groups to maximize the similarities and the differences of information.

In this study, Grounded theory methodology is used. Grounded theory divulges the underlying process of an occurrence in a significant area of 
study (Lowe 1998, p. 106). This theory is evolved by Glaser and Strauss (1967). In this methodology, a theory is generated through an organized set of activities from data by means of reiterative loops of inductive and deductive reasoning. This method of research is adopted to study written and spoken data for generating codes (Greener 2008) for building up a new theory by means of qualitative data (Glaser 2001, 2003). It needs a high level of intuition and analytical sensitivity. First of all, interviews are conducted then transcribed. The transcription is read several times to identify essential links related to the situation. When the researcher read the transcriptions repeatedly, the process furthers to develop Open Codes. Then these Open Codes are converted into a high level of abstraction called Axial Codes. At this stage, the researcher gets a paradigm model. The next step is to generate the phenomena and explain all the causal conditions, strategies, and consequences to prepare Selective coding to identify the core category. At last, the results are discussed, and recommendations are given.

\section{Open Coding}

Open coding is the first step of the Grounded theory analysis in which the qualitative data is split up into familiar concepts which are "tags, incidents, events or happenings related to the phenomena" (Straus and Corbin, 1990). Each concept is thoroughly "paralleled with other ideas, events, and happenings to judge the match and contrast" (Corbin and Strauss, 2008). These concepts are termed as open codes. Some 22 codes were recognized and then tagged.

This chapter focuses and explains all those pertinent codes. In this stage, codes are explained according to their properties and dimensions. These properties show their characteristics across dimensions and help in positioning the codes. They are given properties and dimensions because it helps in axial coding where the concepts are narrow down for getting a high level of abstraction. Further codes are presented in tabular form for ease of understanding, and a complete list of open codes are provided in Appendix 2. The detailed explanation of 22 codes is given below. 


\section{Shari'ah Compliance}

\begin{tabular}{|l|c|c|}
\hline Open Code & Properties & Dimensions \\
\hline \multirow{3}{*}{ Shari'ah Compliance } & Level & Low/High \\
\cline { 2 - 3 } & Understanding & Less/More \\
\cline { 2 - 3 } & Implementation & Good/Bad \\
\hline
\end{tabular}

This open code is developed by continually comparing the views of different managers and customers. Islamic banks operate under the umbrella of Shari'ah rules and regulations. Islamic banks have to follow these rules because it is the base \& the differentiating factor between Islamic and conventional banking. Violating these rules is hurting the essence of Shari'ah.

"Shari'ah rules are important for securing the sanctity of Islamic Banks." (Area Manager)

The Shari'ah Compliance code will lead us towards a level, an understanding, and implementation of Shari'ah rules for both the manager and the customer. It is also essential in the context of investigating the customers' know-how about the Islamic Bank's products, his knowledge regarding Shari'ah, and the benefits he receives from Shari'ah rules. The level of Shari'ah is "High" as perceived by managers.

"Our customers know that we are Shari'ah-compliant." (Credit Manager)

The customer still needs more information regarding the products of Islamic Banks, and further understanding of Islamic Banks will take time as perceived by different managers. Islamic Banking is recently introduced in contrast to Conventional banking, which has been operating for a long time. Most of the Islamic Bank's clients are the ex-customers of traditional banks.

"Customer understands Islamic banking less than conventional banking." (Manager Advances)

The most important aspect is the Shari'ah rules implementation and adoption for both the customer and manager. Shari'ah board is responsible for instructing the mufti's which further directs managers, and finally, managers deal with customers, so coordination and righteous intentions are necessary for full implementation of Shari'ah rules.

"Implementation of Shari'ah is a difficult task for both the Shari'ah board and the managers, and still, more perfection is required to achieve by the Islamic banks." (Area Manager) 
2. Loan Seeker

\begin{tabular}{|l|l|l|}
\hline Open Code & Properties & Dimensions \\
\hline \multirow{3}{*}{ Loan Seeker } & Level & Majority/Minority \\
\cline { 2 - 3 } & Purpose & Clear/Vague \\
\cline { 2 - 3 } & Motive & Follow/Unfollow \\
\hline
\end{tabular}

The Code "Loan Seeker" has been developed because different Managers opines that most of their customers access Islamic Banks just for taking a loan. There is no concept to advance money in the form of a credit for profit in Islamic Banking because that gain on loan merely is Interest. Interest on loans is forbidden in Islamic Law but, it does not mean that all sorts of benefits of capital are banned. The increment sought over the principal amount of the debt is prohibited. Islamic Law endeavors merely prohibition of a risk-free return and promotion of trade. Quran enshrines that trade, in an Islamic Financial setup makes financial activities real asset-backed with aptness to cause 'value addition.' This Code will lead us toward the level, purpose, and motives of the customer being a "loan seeker."

"Customer normally applies for a loan." (Manager Advances)

"Customer wants to get loan mostly." (Corporate advancement Manager)

Customers also perceived that they apply for a loan in Islamic banks. There may be limited information with the customer, or he merely wants to get a loan either from Islamic Bank or Conventional Bank. The motives of the customer play a vital role, whether he will follow the Shari'ah rules or not.

"Being a regular customer of Islamic Banks, I have got a loan from

them for so many times as compared with Conventional Banks.."

(Customer)

Violation of the rules can happen for both parties because the customer wants to get a loan and the manager wants to advance credit so they may hurt the sanctity of Shari'ah for their benefits as per their responses.

Banks usually check the purpose of the customer for which he is applying for a loan. Customers with a clear intent are welcomed as perceived by managers.

"Banks do not grant a loan to a customer with a vague proposal." (Credit Manager) 


\section{Unneeded Products}

\begin{tabular}{|l|l|l|}
\hline Open Code & Properties & Dimensions \\
\hline \multirow{3}{*}{ Unneeded products } & Level & $\begin{array}{l}\text { Low demand/ } \\
\text { High demand }\end{array}$ \\
\cline { 2 - 3 } & Customer awareness & Low/High \\
\cline { 2 - 3 } & Bank acceptance & Low/High \\
\hline
\end{tabular}

This code has emerged through constant comparison of the views of the customers and the managers. Islamic Banks provide product-based services while customers approach for taking funds against different products. There may be some smart customers who can come with proposals having invalid product demand. Islamic Banks should ensure a vigilant eye regarding the products being demanded by the customers.

"Customer applies for products they normally don't want." (Credit Manager)

Islamic banks extend financing to customers having a crystal clear proposal. Customers make unneeded demands, but those are not accepted, as perceived by the managers.

"Customer having the invalid purpose of the investment is not welcomed." (Credit Manager)

Awareness of the customer is a most significant factor in this discourse, because this may be due to his/her misunderstanding or lack of knowledge about Islamic Banks' services, that he/she demands a loan with invalid proposals. Shari'ah rules instruct us to know the purpose of the customer because he/she may invest this money in some Haram businesses.

"Islamic banks have a clear policy of advancement within the jurisdiction of Shari'ah rules." (Manager Advances)

\section{Contractual Requirements}

\begin{tabular}{|l|l|l|}
\hline Open Code & Properties & Dimensions \\
\hline \multirow{3}{*}{$\begin{array}{l}\text { Contractual } \\
\text { requirements }\end{array}$} & Understanding & Low/High \\
\cline { 2 - 3 } & Fulfillment & Less/More \\
\cline { 2 - 3 } & Violation & Less/More \\
\hline
\end{tabular}

This code has emerged through continually comparing the views and ideas of the managers and the customers. The existence of a business is dependent on oral \& written agreed words known as contracts. Adherence to these requirements is a must for both the customer and manager. When there are problems in the understanding of the agreement, then its fulfillment becomes a question mark. 
"There are some rules and regulation which binds up the customer and the manager." (Credit Manager)

Islamic banks are quite zealous about the contractual requirements which they need to fulfill while extending services to their customers. They take care of all those measures required to meet a contract. In Conventional Banking, such contractual requirements are decidedly less, and prior customers of Conventional Banks are not used to with such abundance of contractual requirements so those customers might be uneasy while fulfilling such conditions which could be a disadvantage for Islamic Banks as opined by the managers.

"We go through different detailed steps which make the customer confused."(Credit Manager)

Islamic banks do not compromise on leaving off any of the steps in their process because the Islamic contract is a chain of activities carried on one by one by the manager and the customer.

"We do not miss the sequence of steps, and all steps are carried out thoroughly."(Corporate Advancement Manager)

\section{Religious Victimization}

\begin{tabular}{|l|l|l|}
\hline Open Code & Properties & Dimensions \\
\hline \multirow{3}{*}{$\begin{array}{l}\text { Religious } \\
\text { Victimization }\end{array}$} & Intensity & Less/More \\
\cline { 2 - 3 } & $\begin{array}{l}\text { Shari'ah's board/ } \\
\text { Mufti's role }\end{array}$ & Low/High \\
\cline { 2 - 3 } & Manager's role & Low/High \\
\hline
\end{tabular}

This Code has developed through a recurring comparison of different customers' and managers' views. Conventional banking is present for decades, and most of the customers were involved in Traditional Banking. After the introduction of Islamic banking, they transferred their accounts from Conventional to Islamic Banks. These customers left Conventional Banks for the sake of Shari'ah-compliant Islamic banking.

"We mostly deal with ex-customers of conventional banks." (Area Manager)

The Islamic Banks also got an edge by hiring those former Conventional bankers and received a good customer base through their hired personnel. They attracted their customers with Shari'ah-compliant banking, which is a preferred way of Banking for them due to their religious sentiments.

"Our customers are fed-up with Conventional Banking, and we provide them with full fledge Shari'ah-compliant banking." (Corporate Advancement manager) 
This Open Code shows that Islamic Banks might be involved in customer victimization. Customers with religious attachments lure towards Islamic Banking due to their religious sensibilities ignoring the fact of their satisfaction with such way of banking. The role of a Mufti and the Manager in this discourse is of much significance because the Shari'ah Board is the policymaker and the Manager is the practitioner. Customers may not understand victimization because of their vagueness in the arena of Islamic banking.

"There is one Mufti for more than 120 branches."(Manager Advances)

6. True Refuge

\begin{tabular}{|l|l|l|}
\hline Open Code & Properties & Dimensions \\
\hline \multirow{3}{*}{ True Refuge } & Level & Less/More \\
\cline { 2 - 3 } & Advantage & Narrow/wide \\
\cline { 2 - 3 } & Customer retention & Yes/no \\
\hline
\end{tabular}

This code has been developed from the interpretations of the manager's views. A customer who has been dissatisfied with conventional banks for a protracted period approaches an Islamic bank for refuge. If he/she is utterly rescued, then we call it True Refuge. It may lead the bank to customer retention and higher profits.

"Most of our customers are the victims of conventional banks, and they are sick of it." (Corporate Advances Manager)

Islamic banks try to provide refuge regarding full Shari'ah-compliant banking and don't hurt the sanctity of Shari'ah and customer religious beliefs. A customer of Islamic bank comes just because of his/her religious belief as perceived by managers.

"Customer considers Islamic banks the last resort for being rescued." (Manager Advances)

We have provided full fledge Shari'ah-compliant banking in term of True Refuge, and the customer gets the advantages too. The True Refuge has also helped us in retaining the customers as perceived by managers.

"Islamic loan is full of benefits as compared to conventional loan and we will utilize it in future also." (Customer)

\section{Exploitation}

\begin{tabular}{|l|l|l|}
\hline Open Code & Properties & Dimensions \\
\hline \multirow{3}{*}{$\begin{array}{l}\text { Zero } \\
\text { refuge/Exploitation }\end{array}$} & Intensity & Low/High \\
\cline { 2 - 3 } & Customer's Knowledge & Less/More \\
\cline { 2 - 3 } & Customer retention & Yes/no \\
\hline
\end{tabular}


This Code appears in the enlightenment of those views which the managers have put forward in their responses. A customer of the conventional bank wants to get refuge in Islamic bank because he/she is tired of interest based Conventional Banking. Customers tend toward Islamic Banks because of their trust, faith, and confidence in Shari'ah-compliant banking.

"Customer does not want to pursue conventional banking because they have a good alternative according to their faith and belief." (Credit manager)

When a customer, who endeavors Shari'ah-compliant banking is misguided and distrusted, then it is called as exploitation. Customers are fully supported and not thwarted because banks do not want to lose them as perceived by managers. Customer's spiritual perception can be hurt too, if there are problems in providing Shari'ah-compliant banking.

"We strive to accommodate the customer's needs comprehensively, in boundaries of Shari'ah." (Area Manager)

Banks can exploit the customer because of their inadequacy in understanding Islamic Banking. If banks are misusing the customers, then it is impossible for the bank to retain them.

"Customer will fully understand Islamic banking with the passage

of time." (Advances Manager)

\section{Religious belief}

\begin{tabular}{|l|l|l|}
\hline Open Code & Properties & Dimensions \\
\hline \multirow{4}{*}{ Religious belief } & Faith & Strong /weak \\
\cline { 2 - 3 } & Bank's meticulousness & Less/More \\
\cline { 2 - 3 } & Customer care & Less/More \\
\cline { 2 - 3 } & Perception & Good/Bad \\
\hline
\end{tabular}

This code emerged through a consistent comparison of the customer's and the manager's views. Religious belief means the belief in various aspects of religion like spiritual, supernatural. The customers of Islamic banking come with a motive of Shari'ah rules and regulation. They have respect for Islamic values, and they have a strong faith in Islamic banking as perceived by managers.

"Our customers have a strong faith and conviction in Islamic banking." (Manager Advances)

Islamic banks are meticulous about customers' religious predilections because customers' attraction is directly proportional to it. They facilitate customers with full fledge Islamic banking when they are no happier with conventional banking. We have a complete set of Shari'ah-compliant products which can benefit the customer as maintained by managers. 
“Islamic banking products are beneficial to customers' needs and wants." (Area Manager)

Customer intentions determine their willingness to follow Shari'ah rules and regulation. Good intentions lead to the excellent implementation of Shari'ah rules and vice versa. Good intentions also help the bank in executing Shari'ah rules properly, otherwise bank cannot do anything against customer terrible plans in some cases as perceived by managers. There is a contradiction in the views of the manager because on one side, they claim that their customer come due to Shari'ah and on the other hand they say, we are barred against the customer's terrible intentions.

"Execution of Shari'ah is dependent on customer intentions."

(Credit Manager)

Our customers have a good perception as compared to conventional banking, and they have experienced that Islamic loan is full of benefits. They are motivated in this regard and have further plans to take a credit from Islamic bank as perceived by managers.

"Islamic loan is good and convenient in repayment."(Credit manager)

\section{Shari'ah Objectives}

\begin{tabular}{|l|l|l|}
\hline Open Code & Properties & Dimensions \\
\hline \multirow{4}{*}{ Shari'ah Objectives } & Significance & Low/high \\
\cline { 2 - 3 } & Advantage & Narrow/wide \\
\cline { 2 - 3 } & Fulfillment & Less/more \\
\cline { 2 - 3 } & $\begin{array}{l}\text { Customer } \\
\text { Understanding }\end{array}$ & Low/high \\
\hline
\end{tabular}

This open code has evolved through the discussions with managers. Managers put their views while differentiating between Islamic and Conventional Banking; they said the subject matter of a contract in traditional banking is money, and in contrast, Islamic Banking dealings depend upon the asset or investment. So, for Islamic bankers, the phenomena behind this asset and investment-based banking is the Shari'ah objectives. Shari'ah objectives are the core theme of Islamic banking and the reason for its existence as maintained by the managers.

"Islamic banking is performed with the aim to achieve the Shari'ah objectives." (Credit Manager)

Islamic banks will be on the safer side if they prefer Shari'ah objectives over profit. A customer comes to avail Shari'ah-compliant banking so if the bank is providing the Shari'ah-compliant banking then both the customer and the bank will take benefit from it as perceived by managers. 
"Achieving the Shari'ah objectives has a dual benefit, i.e., for both the customer and the bank."(Manager Advances)

\section{Malpracticing/fraudulent activities}

\begin{tabular}{|l|l|l|}
\hline Open Code & Properties & Dimensions \\
\hline \multirow{3}{*}{$\begin{array}{l}\text { Malpracticing/fraudulent } \\
\text { activities }\end{array}$} & Existence & Low/high \\
\cline { 2 - 3 } & Responsibility & Manager/customer \\
\cline { 2 - 3 } & Control & Low/high \\
\hline
\end{tabular}

This open code is developed by discussing the credit issues with the manager. The phenomena of Malpracticing/fraudulent activities include all those unethical and illegal activities which one does beyond its jurisdiction or the boundaries of the Shari'ah rules. Shari'ah rules should be availed to avoid malpracticing.

This code will describe the existence, responsibility, and control of malpracticing. There are some cases where the Shari'ah board has caught malpracticing as regarded by different managers. Every manager visited by the researcher admitted somewhat malpracticing except one or two.

"There are many cases of malpractice." (Area Manager)

"The manager was responsible in one case because of his laziness."

(Corporate advancement manager)

Both the customer and manager does Malpractices. Some managers put the whole responsibility on the customer, but some admit the mistakes of their managers. Manager and customer have to play their roles accordingly.

"Yes, we have some cases of mall-practicing in the past." (Area Manager)

Malpracticing can be controlled through demotion, strict laws and penalties by the bank as perceived by managers. Malpracticing cannot be managed because the customer can legally cheat bank and the bank cannot do anything, according to some other managers.

"A manager faced demotion because his lower staff was involved in fraudulent activities." (Manager Advances)

"We have introduced strict laws which are helpful in avoiding such actions." (Area Manager)

11. Strict Shari'ah laws

\begin{tabular}{|l|l|l|}
\hline Open Code & Properties & Dimensions \\
\hline \multirow{3}{*}{ Strict Shari'ah laws } & Introduction & Soon/late \\
\cline { 2 - 3 } & Implementation & Good/bad \\
\cline { 2 - 3 } & Effect & Good/bad \\
\hline
\end{tabular}


This open code has evolved through repeated comparisons of different manager's views. The law means a system of rules used for controlling human behavior through social institutions. When the Shari'ah board caught some cases of malpracticing, they introduced some strict regulations. They aimed to halt these violations which injure the essence of Shari'ah. In some banks, the introduction of strict rules was late, although, but the current effects are sound as understood by the managers.

\section{"After facing some cases of malpracticing, the Shari'ah board has} introduced some strict rules and regulation." (Area Manager)

The advancement process at all banks is quite explanatory and stepwise. We try to stop violation of Shari'ah Regulations. Laws are made for effective and efficient implementation as perceived by the managers.

"From now onwards, our rules became so strict that dodging of Shari'ah compliance is impossible in some contracts especially." (Credit manager)

Anything planned and done with supervision and care has fruitful effects. Islamic banks are now getting good results after the introduction of strict laws because they have a fierce competition ahead with each other and conventional banks as perceived by managers.

"The last resort to survive in this competition is to ensure the exact implementation of Shari'ah." (Credit Manager)

\section{Manager's willingness}

\begin{tabular}{|l|l|l|}
\hline Open Code & Properties & Dimensions \\
\hline \multirow{3}{*}{ Manager's willingness } & Intentions & Right/wrong \\
\cline { 2 - 3 } & Involvement & Less/more \\
\hline
\end{tabular}

This open code is developed from manager's views and comments. The process of banking is dependent on both customer and manager because they are the direct stakeholders. While performing the bank operations manager is responsible for what he does. A manager having good intentions to follow Shari'ah will proceed with exact Shari'ah rules and regulation and vice versa. Being an insider, the manager knows so many hidden things which the customer does not do as perceived by managers.

"We always say the manager is our key executor of Shari'ah and his performance may have a good or an adverse effect." (Area Manager)

When we discuss the involvement of managers in malpractices then once again, we quote the intentions of manager because Islamic banks claim that there is no other pressure on him/her. There may be some other reason for involvement, i.e., negligence. 
"The manager may do something against Shari'ah because of his negligence not with a motive to hurt the essence of Shari'ah." (Manager Advances)

\section{Customer Intentions}

\begin{tabular}{|l|l|l|}
\hline Open Code & Properties & Dimensions \\
\hline \multirow{4}{*}{ Customer Intentions } & Nature & Right/wrong \\
\cline { 2 - 3 } & Shari'ah board/mufti's role & Low/high \\
\cline { 2 - 3 } & Manager's role & Low/high \\
\cline { 2 - 3 } & Control & Right/wrong \\
\hline
\end{tabular}

This code evolved due to the involvement of customers in the process of credit advancement. This code will explain the nature, the role of Shari'ah board or mufti, manager's role and the control by the bank on customer intentions. Some managers have highlighted that customer, with evil plans cannot be stopped by the bank and the Shari'ah board or the mufti. The customer can sort out ways where he can legally do illegal work. If a customer has a firm belief in Islam/Shari'ah, then he can pursue the Islamic banking in a real sense otherwise not, as perceived by the manager.

"Customer has no constraints in proceeding with wrong intentions.” (Manager Advances)

The role of mufti as well as of a manager will not make any difference according to a manager, as far as the customer has evil intentions. However, the Shari'ah board can find out ways to stop customer dodging the Islamic bank as perceived by the manager. Customer needs some more information to get used to with Islamic banking as viewed by managers.

Shari'ah board and managers are the key stakeholders in the process of Shari'ah rules' implementation (Islamic credit advancement). They can play their roles in educating the ignorant customer as well as stopping them from cheating.

"Banks have to deal every type of customer." (Credit Manager)

14. Managerial deficiency

\begin{tabular}{|l|l|l|}
\hline Open Code & Properties & Dimensions \\
\hline \multirow{3}{*}{ Managerial deficiency } & Laziness & Low/high \\
\cline { 2 - 3 } & Work environment & Favorable/unfavorable \\
\hline
\end{tabular}

This open code is developed from the views of respondents. When a manager is unable to perform its function and duties, then managerial deficiency will exist. Manager links the top and lower management with each other because it represents the middle management of the organization. 
Laziness is a factor which creates a managerial deficiency, especially in Islamic Banks. We have found some cases where the managers' laziness have caused malpracticing as perceived by managers.

"Managers laziness sometimes lead to managerial deficiency." (Manager Advances)

There is a predominant influence on the working environment on human performance. Managerial deficiency may be present because the employees have to do the job in an unfavorable environment, i.e., clashes with colleagues, misunderstandings with the boss and other problems like load shedding, workload. The Islamic banking tedious process can be another reason for managerial deficiency as recognized by managers.

"Manager has more work burden and engagement with the customer." (Area Manager)

15. Mufti's role

\begin{tabular}{|l|l|l|}
\hline Open Code & Properties & Dimensions \\
\hline \multirow{3}{*}{ Mufti's role } & Bank visit & Less frequent/most frequent \\
\cline { 2 - 3 } & Process involvement & Less/more \\
\cline { 2 - 3 } & Flaws identification & Low/high \\
\hline
\end{tabular}

This open code is developed by continually comparing manager views. The role of mufti is to supervise the Islamic bank's personnel and identify all those flaws which halt Islamic banking. This code will lead us to Mufti's bank visit, how much he is involved in the credit advancement process and his ability to identify flaws.

Some managers said that there are few muftis for more branches and mufti sahib also don't know more about the procedures in some banks, so flaws identification is a bit difficult for them being a superior authority responsible for full implementation of Shari'ah.

"Role of Shari'ah Auditor is limited, and he visits less frequent." (Credit Manager)

Some managers are of the view that the Mufti's frequent visit to the bank keeps the bankers tight enough with guidance regarding Shari'ah principles. The bank has also involved them in the process to increase their understanding regarding the market. They are also able to identify the flaws and stop malpracticing.

"The strict laws plus complete supervision of Shari'ah Auditor helped us more in avoiding different Haram activities." (Area Manager) 


\section{Costly Contracts}

\begin{tabular}{|l|l|l|}
\hline & Properties & Dimensions \\
\hline \multirow{3}{*}{ Costly Contracts } & Level & Low/high \\
\cline { 2 - 3 } & Tedious process & Less/more \\
\cline { 2 - 3 } & Customer loss & Low/high \\
\hline
\end{tabular}

This open code is developed in responses received from different managers. Islamic banks follow stepwise procedures in carrying out their various tasks, and it changes from the conventional banking. As most of the Islamic bank's customers are the ex-customers of traditional banks, so they face problems because they used to do one-time documentation. Now they have issues with more visits to the bank for the fulfillment of different Islamic bank requirements as perceived by managers. Islamic banking contracts need rescheduling, and the termination charges are also more than conventional banks as observed by managers.

"Islamic banking is not so user-friendly as conventional banking."

(Manager Advances)

The most important factor over here is customer wills because if he/she has some real passion for his/her religion or religious belief, then he will bear all these problems calmly. It may not cause the loss of those customers having a passion for Islamic banking, and the comfort lovers may leave the Islamic banks.

"Customers having strong beliefs do not mind visiting the bank frequently." (Manager Advances)

\section{Manager punishment}

\begin{tabular}{|l|l|l|}
\hline Open Code & Properties & Dimensions \\
\hline \multirow{3}{*}{ Manager punishment } & Demotion & Yes/no \\
\cline { 2 - 3 } & Fired out & Yes/no \\
\cline { 2 - 3 } & Effect & Yes/no \\
\hline
\end{tabular}

This code has evolved through discussions with managers. When Shari'ah Board catches a Manager involved in malpractice, then he is charged with penalties in the form of demotion or is even fired out. There are some cases where the manager was demoted in Islamic banks as perceived by managers.

"The manager's lower staff was involved in illegal activates so he was demoted."(Corporate Advancement Manager)

Some banks may have the policy to fire out their manager involved in malpractices. However, there is no evidence of a case of firing out the manager in any Islamic bank as perceived by the managers. 
"We have not experienced any fired-out case of managers in our bank." (Credit officer)

Managers think that punishment policy will restrain managers from indulging in any illegal activity. The system should be precise enough to avoid any confusion in implementation.

"Manager will never involve in activities hazardous to his job, career." (Credit Manager)

\section{Cost lead Customers}

\begin{tabular}{|l|l|l|}
\hline Open Code & Properties & Dimensions \\
\hline \multirow{3}{*}{ Cost lead Customers } & Level & Majority/Minority \\
\cline { 2 - 3 } & Bank's attention & Low/High \\
\hline
\end{tabular}

This open code is evolved through the discussions with managers. Banks deal with individuals as well as corporate customers who are involved in different businesses. They have different goals and objectives to achieve, with a different state of minds. These customers take care of their profit and loss as per their aspirations. Islamic credit advancement is mostly used by corporate customers for their business as perceived by managers.

"We mostly advance loans to corporate customers." (Credit Manager)

Islamic banking is in its initial stages, and it needs further improvement and development. The Customers of Islamic banking also have less knowledge regarding the Shari'ah compliance which makes problems in the implementation of Shari'ah as perceived by managers.

"Customer will take time to understand the Islamic banking rules."

(Credit Manager)

The profit motive of the customers hurts the essence of Shari'ah because they do not care about Shari'ah. Instead, they care about their profits. The customers opt for those contracts which are less costly, and there is more profit for them. Even the customer does not care about the understanding of Shari'ah, but just his gain is vital for him/her as perceived by managers.

"Customer comes with a motive to spend less and earn more"

(Credit in Charge)

"We deal mostly the profit seekers." (Credit Manager) 
19. Competition with the Conventional bank

\begin{tabular}{|l|l|l|}
\hline Open Code & Properties & Dimensions \\
\hline \multirow{2}{*}{$\begin{array}{l}\text { Competition with the } \\
\text { Conventional bank }\end{array}$} & Intensity & Low/High \\
\cline { 2 - 3 } & Shari'ah Misuse & Low/High \\
\hline
\end{tabular}

This open code is developed from the views of respondents. The existence of rivalry is a common factor present in every sort of business. Islamic banks are also facing the same problems. Their rivals have a strong background based on past experiences. It means to say the conventional bank is the harsh competitor of Islamic bank as observed by the managers.

"The ultimate threat to Islamic banking is the long-lasting conventional banking."(Credit Officer)

Islamic banks have started their operations in the recent past, and they have to survive and face market competition. Their policies are differentiated from those of the conventional banks because of Shari'ah compliance. Shari'ah compliance is a step by step procedure which the Islamic banks have to follow. They will hurt the essence of Shari'ah if they violate the Shari'ah compliance rules.

"Islamic banking is based on Shari'ah compliance, which is like a role model to follow."(Credit Manager)

The detailed observation of Shari'ah seems difficult sometimes, and they skip some steps for outclassing the competition. If Islamic banks want to exist in the market, then they have to make compromises regarding Shari'ah rules as discerned by the managers.

"Customer will not deal with us if we do not care about their profits." (Credit in Charge)

20. Pressure of Management

\begin{tabular}{|l|l|l|}
\hline Open Code & Properties & Dimensions \\
\hline \multirow{2}{*}{ Pressure of Management } & $\begin{array}{l}\text { Effect } \\
\text { manager }\end{array}$ & Low/High \\
\cline { 2 - 3 } & $\begin{array}{l}\text { Shari'ah } \\
\text { avoidance }\end{array}$ & Low/high \\
\hline
\end{tabular}

This code is developed from the views of managers. Management is divided into three levels, i.e., top, middle and lower management. Islamic banks have the same set up just like other banks and organizations. They have senior management responsible for the policy-making and Shari'ah scholars for help regarding Shari'ah compliance, Shari'ah audit. 
"Islamic bank top management formulates policies and also monitors the performance." (Manager Advances)

When top management does not support middle managers and stress him to accomplish the task, then he/she might go beyond Shari'ah jurisdiction. The manager will not feel good while performing his/her duties. There is a chance of mall practicing in case manager is not supported by top management as perceived by some managers. Some Islamic banks have this problem that they care more about shareholder value creation rather than Shari'ah compliance by up-getting more stress on employees as noted by managers.

"The top management does not give any relaxation to managers in accomplishing tasks." (Credit Manager)

\section{Staff Background}

\begin{tabular}{|l|l|l|}
\hline Open Code & Properties & Dimensions \\
\hline \multirow{3}{*}{ Staff Background } & Level & Low/High \\
\cline { 2 - 3 } & Shari'ah compliance understanding & Low/high \\
\hline
\end{tabular}

This code has been developed from the discussions with the managers. Islamic banking can be divided into two types, i.e., full-fledged Islamic banks, and Islamic windows of conventional banks. Both of these types face the lack of qualified staff having a vast Islamic banking background. That is why they hire the ex-employees of traditional banks or use the same team of conventional setup in Islamic windows as perceived by managers.

“... Most of our employees have the conventional background, and they face the problems in Islamic banking operations." (Credit in Charge)

There are at least three categories of Islamic banking employees. The first category includes that retired or experienced personnel of Conventional Banks, who know the market and have a full understanding of conventional banking. They are appointed to higher positions in the management, i.e., area manager, regional manager in Islamic banks as perceived by managers.

"Employees having vast experience in conventional banking are awarded good managerial positions because they have good contacts in the market." (Credit Manager)

The second category consists of those credit managers/managers who have some Islamic academic background. They understand both the Shari'ah compliance as well as the general banking. They are directly involved with the customer in credit advancement. 
"Our credit managers are more efficient in understanding Shari'ah and banking." (Area Manager)

The third category cooperates with the credit manager in different documentation and sometimes deals with customers who have less knowledge. Knowledgeable customers are carried forward to credit manager. The Islamic windows allocate these personnels from their conventional setups and their understanding regarding Shari'ah Compliance is considered minor as perceived by the managers.

"If the lower staff has some problems in dealing with the customer then they consult the credit manager for help and problem solution." (Credit in Charge)

\section{Documented Shari'ah Compliance}

\begin{tabular}{|l|l|l|}
\hline Open Code & Properties & Dimensions \\
\hline \multirow{3}{*}{$\begin{array}{l}\text { Documented Shari'ah } \\
\text { Compliance }\end{array}$} & Level & Low/High \\
\cline { 2 - 3 } & Shari'ah board/mufti response & Less/More \\
\cline { 2 - 3 } & Upper Management response & Less/More \\
\hline
\end{tabular}

This open code was evolved while going through the analysis of different manager interviews. Shari'ah compliance is defined as, "the set of banking and finance rules implemented according to Islamic law or under the jurisdiction of Islamic law."

"Islamic law is the backbone of Shari'ah-compliant banking and finance." (Area Manager)

Shari'ah Compliance is the $\mathrm{x}$-factor of Islamic Banking because the traditional way of banking is strong enough to outclass the Islamic banks. Islamic bank attracts customer due to this factor, so the need to follow Shari'ah arises strongly.

"We are getting good customer base because of the stamp of Shari'ah compliance."(Credit Manager)

Shari'ah-compliant banking is carried out in proper steps, and rules are specified for every step/transaction. These steps should be carried out in the same manner prescribed by the Shari'ah laws. The follow-up needs time and affects their performance regarding fewer transactions done by the bank's employee. Now there starts a struggle between the employee's goals (targets) and fulfilling Shari'ah objectives. This issue creates confusion leading to manipulation of the Shari'ah rules and confinement of the Shari'ah Compliance to formal documentation. This scenario can be termed as documented Shari'ah compliance. They skip some steps essential to be followed, and the customer is provided with some relaxation for the sake of 
the transaction fulfillment. These activities cannot be considered illegal or not according to Shari'ah because the formal documents are complete to show in Shari'ah audit or mufti's visits.

"Following the Shari'ah rules need time and managers to perform different visits." (Manager Advances)

\section{Axial Coding}

Axial coding is the narrowing down of the concepts identified in Open Coding to get more accurate ideas. They are developed by consolidating all the similar open codes under one head. It is "the second stage of grounded theory analysis in which axial codes are drawn." (Straus and Corbin, 1990)

The sole purpose of stitching the data (axial coding) is to make relationships among the scattered ideas explained in open coding. A paradigm model is used to link all the connections at this stage of analysis as suggested by Strauss and Corbin (1990). The paradigm model is the critical analytical tool used in this and the upcoming chapter. In this chapter, it combines the results of paradigm model in each axial code in the statements while in the next section it will explain all the parts of the paradigm model in a sequence. It is done to uncover the process of discovering the core category.

The analysis in this chapter is premature, and one has to study the next section (Selective coding) for a complete understanding of the core phenomena. Some open codes have saturation and improvement in them so they can become axial codes directly, i.e., the pressure of management, staff background and documented Shari'ah compliance (see 2.21, 2.22 and 2.23). Axial codes are combined based on their dimensions through the use of paradigm model.

\section{Managerial Attitude}

\begin{tabular}{|l|l|}
\hline Axial Category & Open Category \\
\hline \multirow{3}{*}{ Managerial Attitude } & Managerial Deficiency \\
\cline { 2 - 2 } & Managerial Willingness \\
\hline
\end{tabular}

In this axial code, two open codes are combined, based on their properties and dimensions. The open codes, managerial deficiency and managerial willingness, are merged into a high-level abstract form called "managerial attitude." This general category will explain the role of the manager in the Implementation of Shari'ah in Islamic banks.

Attitude is a state of mind which leads the behavior of an individual or person. The attitude of the manager has a significant role in the 
implementation of Shari'ah. Islamic banks have the same management structure as other banks and institutions and the same traditional hierarchy of assigning managerial posts is followed.

Islamic banks operate under the rules of Shari'ah which make them isolated from the Conventional Banking. They are advised by the Shari'ah board/mufti in matters like Shari'ah policy while managers handle the management and implementation of Shari'ah issues.

"The Shari'ah board/mufti has no role in management issues except the Shari'ah check." (Area Manager)

The effect of managerial attitude on Shari'ah implementation is obviously crystal clear. Manager role is as of a driver, and the Shari'ah board is his/her guide. It is the responsibility of the manager to drive correctly while the mufti will show the direction or the destiny.

Both of the open codes have commonalities in properties and dimensions, and the new category that is, the managerial attitude has a significant effect on Shari'ah implementation. The managerial approach is not up to the mark, according to the Open Codes developed from respondent's views. Managerial deficiency is less significant as compared to managerial willingness for Shari'ah implementation.

The more prominent threat to Shari'ah is the willingness of manager because he is the concerned person responsible for Shari'ah implementation. If he is not willing, then Islamic banking has no purpose as such, and there will be no difference between Islamic and conventional banking.

In a nutshell, most of the managers are less willing to implement Shari'ah because they are more devoted towards their targets. Their attitude is negative in this regard, according to the study conducted.

"We have to accomplish our targets, according to the instruction we get." (Credit Manager)

\section{Shari'ah Compliance}

\begin{tabular}{|l|l|}
\hline Axial Code & Open Category \\
\hline \multirow{4}{*}{ Shari'ah Compliance } & Mufti/Shari'ah Board Role \\
\cline { 2 - 2 } & Manager Punishment \\
\cline { 2 - 2 } & Strict Shari'ah Laws \\
\cline { 2 - 2 } & Shari'ah Objectives \\
\hline
\end{tabular}

In this axial category, we have a bunch of open codes. These open codes are grouped together based on their properties and dimensions. Shari'ah 
compliance is the distinguishing factor of an Islamic bank and their slogan of change from the conventional setup.

This axial code consists of open codes like Mufti/Shari'ah Board Role, Manager Punishment, Strict Shari'ah Laws and Shari'ah Objectives. All the open codes have their significance in Shari'ah compliance, but Shari'ah objectives and mufti/Shari'ah board role are more important to highlight.

Manager punishment can help the bank in promoting Shari'ah Compliance and further, no manager will involve in malpractice. We have found some cases of manager punishment in our study and banks have found fruitful results.

Strict Shari'ah laws will not give a single chance to managers indulging in malpracticing. Banks have found it beneficial after introducing these laws to ensure exemplary Shari'ah implementation. These laws were added a bit later, after some managers were caught while doing illegal activities. For halting such issues, banks have introduced this strict law of Shari'ah.

The role of the Mufti/Shari'ah board cannot be ignored because they are the ultimate authority to control any illegal or beyond Shari'ah activities and implement Shari'ah in its true spirit. The role of the Mufti/Shari'ah board has been restrained to just regular visits. Moreover, they do not know the process flow accurately, and they are not capable of capturing the mistakes made by managers as per the study. They need to be equipped with the exact knowledge of Islamic banking which will make them able to identify the flaws.

Shari'ah compliance is dependent on Shari'ah objectives of the bank. The more the Shari'ah objective will be according to Shari'ah rules the more the bank is Shari'ah Compliant.

Some banks do not have a clear stance on Shari'ah Objectives, which shows their biasedness in the implementation of Shari'ah as per this study.

In brief, Shari'ah Compliance is not confined to the policies of the bank. These policies are implemented entirely in their operations and dealing with the customer. This situation hurts the essence of Shari'ah along with defamation of Islamic banks. 
3. Shari'ah Avoidance

\begin{tabular}{|l|l|}
\hline Axial Code & Open Category \\
\hline \multirow{3}{*}{ Shari'ah Avoidance } & Customer Intentions \\
\cline { 2 - 2 } & Unneeded Products \\
\hline
\end{tabular}

These two open codes can be combined to form a new axial category called as Shari'ah Avoidance. It is a high-level abstract form which represents the above codes. The purpose of Islamic banking is to use and promote Shari'ah rules and regulations because it will help them make customers having religious beliefs.

Avoiding Shari'ah by customers will hurt the sanctity of Shari'ah and Islamic banks will lose its reputation because other customers will consider these same as conventional banks. Islamic banks are required to stop dealing with customers involved in Shari'ah Avoidance.

The axial category Shari'ah avoidance emerged from the open codes based on customer dealing. Managers think that following Shari'ah rules and regulation is directly related to customer intentions. If the customer has affirmative plans with good religious thinking, then he will not violate Shari'ah rules and vice versa. Most of the managers have complained that their customers come with evil purposes and they do not care about Shari'ah rules.

The open code of unneeded products also comes under the head of Shari'ah avoidance. Islamic banks advance funds to those entities having a valid and clear proposal. Some managers have claimed that their customers come with unreasonable product demands.

At last, we can say Shari'ah avoidance is done by the customer of Islamic banks, which is not favorable for Islamic banks as per this study results.

\section{Fraudulent Activities/Malpractices}

\begin{tabular}{|l|l|}
\hline Axial Code & Open Category \\
\hline \multirow{2}{*}{ Fraudulent Activities/Malpractices } & Costly Contracts \\
\cline { 2 - 2 } & Loan Seeker \\
\hline
\end{tabular}

The Open Codes "costly contracts," and "loan seeker" are combinable to form the new high level of abstraction called as "fraudulent activities" or mall practicing. Islam always emphasizes to be fair in every action and conduct. The same concept is applied in Islamic Banks too. Islam has given 
more priority to Muamalat as compare to Ibadat. Both the customer and manager are entitled to this stance of Islam and Islamic banking finance.

Islamic banks follow Shari'ah rules in which transactions/contracts are carried out in a sequence. Following the sequence is compulsory because the claim of Shari'ah-compliant will go wrong in case of violation. The sequence of contracts has made the Islamic agreements expensive as compared to conventional ones. Customer and manager have to meet each other and other parties several times. Repeated documentation also creates problems for Islamic banks because it is must in schedule revision. Termination cost is another problem. In the presence of so many issues, customer tend to be inclined towards malpractices and managers are also involved as per this study.

There is no concept of the loan in Islamic banking because Islamic banks provide funds in product-based financing. Managers of Islamic banks have stated several times in their responses that their customer is a loan seeker. Now, the problem arises that whether a loan seeker will obey Islamic rules or not. Secondly, he can miss utilizing the Shari'ah rules and regulation.

In short, we can conclude that Shari'ah sanctity hurts because of involvement in malpracticing due to expensive contracts on one side and on the other customer being a loan seeker wants to get a loan. He does not care about Shari'ah as per our study.

5. Exploitation of Untapped Market

\begin{tabular}{|l|l|}
\hline Axial Code & Open Category \\
\hline \multirow{4}{*}{ Exploitation of Untapped Market } & Religious Victimization \\
\cline { 2 - 2 } & True Refuge \\
\cline { 2 - 2 } & Religious Belief \\
\cline { 2 - 2 } & Exploitation \\
\hline
\end{tabular}

The open codes that constitute "exploitation of the untapped market" include "religious victimization," "true refuge," and "religious belief," exploitation. They attract new customers and those customers who are fed-up of conventional banking. So, they get a new market which has not been exploited yet.

When Islamic banks serve this market, then the exploitation of customers occurs in the form of religious victimization. The customers, in this market, are not aware of the Shari'ah rules and regulation, so the bank does everything for their profit. The customers come due to their religious conviction, but they are deceived in some cases, where they are not aware of the whole scenario. 
Some banks rescue the customer and don't take advantage of the customer compulsion. Banks have got long-lasting customers because of the true refuge they have provided to them. These banks have secured the sanctity of Shari'ah according to their claim as per this study. They were not involved in exploitation.

Shari'ah compliance banking has gained momentum because of the people inclination due to their religious beliefs. Banks should not exploit the customers because their religious feelings will hurt. There were cases found of misusing people's faith as per the study.

Exploitation can cause too much damage to Islamic banks as well as the sanctity of Shari'ah. As Islamic banking is in its initial stages, so they should avoid every type of exploitation to ensure providing long-lasting services.

In short, it is the responsibility of the bank to serve the customers as per their expectations and does not exploit in any matter.

\section{Customer Attitude}

\begin{tabular}{|l|l|}
\hline Axial Code & Open Category \\
\hline \multirow{3}{*}{ Customer Attitude } & Contractual Requirements \\
\cline { 2 - 2 } & Loan Seeker \\
\hline
\end{tabular}

There are two open categories combined to form a new axial code called as customer attitude. The open codes are contractual requirements and loan seeker. The customer is the most critical stakeholder in banking as well as other industries. Islamic bank's customer is not fully aware of rules and regulation of the Shari'ah.

Customer attitude is sometimes weird to contractual requirements. $\mathrm{He}$ sometimes fails to comply with the bank requirements as per our study. The bank should make him liable to fulfill all the criteria because the contract will become void in the opposite case. Then the Shari'ah essence will not be addressed.

Customer attitude is also not right because he is a loan seeker. Some customers seek a loan and do not take care of Shari'ah. They seek their advantages or privileges received from the banks. The bank should take care in dealing with such customers because they can manipulate the bank. Islamic banks may lose the current status because word of mouth will spread in a lousy manner. So, their prospects may become suspects, and the essence of Shari'ah will be lost too. 
In a nutshell, customer attitude toward Islamic banking and Shari'ah rules should be up to the mark, and the bank should restrict the customer to align with the bank policy. Then it will be possible to implement Shari'ah rules.

\section{Selective Coding}

The previous chapters represented the first two stages of Grounded Theory. In this chapter, the scholar has come up with a paradigm model, and then the relationships in the paradigm model are explained (Strauss and corbin1990). The previous sections were about the codes generated, i.e., open and axial. First, open codes were developed then they were merged into single and more abstract categories called axial codes.

In selective coding, the first step is to describe the whole situation in a storyline and then the core category is identified. Strauss and Corbin pinpointed that the storyline may produce more than one core category, but they stressed on the selection of one category and relating other categories to the core category (Strauss and Corbin, 1998). This study has a single core category developed from the result of several brainstorming exercises.

The detailed analysis is narrowed down into few codes. The entire axial codes relate to the core phenomena through a paradigm model (Strauss and Corbin, 1998). The researcher then went through the raw data repeatedly to confirm the emerging aspects. The following steps will explain the whole process of selective coding.

\section{Storyline}

The benchmark for Islamic banking is the rules and regulation of Shari'ah. Currently, they are going through the stage of development, and fierce competition with conventional banking lies in their way. Most of their management has a conventional background in banking.

Islamic bank managers are the ultimate executors of Shari'ah principles. They are facing problems from other stakeholders in Shari'ah execution, especially upper management and customers. We can specify these problems as external and internal pressures/stress.

The upper management is interested in the achievement of goals and targets by the managers, and their sole objective is to earn a profit. While customer attitude is also profit-oriented, he/she does not care about anything rather profit. The role of monitoring and control authority (Shari'ah board/mufti) is also minor because they do not understand the processes carried out in 
Islamic banks entirely. Despite the external and internal pressures managers' willingness is also crucial in the execution of Shari'ah.

In this scenario, management is struggling to survive in the market by earning a profit for them and their customers. The question arises that while trying to accomplish these goals and objectives in such a dynamic environment, Islamic banks will follow Shari'ah or not or to what extent they are adopting lenient Shari'ah compliance.

In such situation, mutual understanding between managers and customers develops for the achievement of their own goals and objectives. The role of Shari'ah board/mufti has become just an ineffective frequent visit for Shari'ah audit while upper management is happy with the satisfaction of their profit motives.

\section{Identification of the Core Category}

As mentioned in 4.1, the second step in selective coding is identifying a core category after the storyline. It is difficult to determine and name the exact phenomena, but as we go through interviews and analysis, our understandings develop with it.

The researcher tries to identify the core category which meets the requirements like abstracted core category, resembles the data, logical and consistent, and explaining all the relationships of other categories with the core category as suggested by Strauss and Corbin (Strauss and Corbin, 2008). The sessions with a supervisor in developing these phenomena were also helpful which supported and improved the individual work done by the researcher.

The core category we have identified in this study is "Shari'ah Tagging" which reveals "going on" situation. "In grounded theory, we search for what is going on." As we have discussed in a storyline that Islamic banks are operating in a competitive era and they have so many problems. They have to earn profits because most of the business institutions are profit oriented. If they are not making, then it means they will not operate due to lack of customer.

The concept of Shari'ah Tagging means Islamic banks need a tag, a stamp to be Shari'ah verified. They want to exist based on the Shari'ah stamp or slogan. They are not following Shari'ah in actuality because they will lose customers and will vanish from the market. They just put a tag of Shari'ah while the footsteps of Shari'ah are not followed. 
Banks are not responsible for this misuse of Shari'ah, but the customer is also involved. In some cases, the bank is even forced by the customer because he does not care about the Shari'ah rules. He is just a profit seeker. He will go for more profitable options.

\section{Paradigm Model}

The paradigm model is used to explain the relationships of axial codes with the core category in grounded theory approach. It is the "logical strategy used to incorporate structure with procedure" (Corbin and stares, 2008). The core category we have identified is Shari'ah Tagging. Paradigm model has the following parts, i.e., causal conditions, core phenomena, strategies and consequences which is used as a crucial tool to relate the core category with other axial codes (Strauss and Corbin, 2008). In our study, we have distributed axial codes according to their relationship and context and then fit them into the model. We have the following causal conditions, i.e., Shari'ah compliance, managerial attitude, customer attitude, competition with conventional banks and exploitation of the untapped market. The strategies used by banks are Shari'ah avoidance, Fraudulent Activities/Malpractices, Pressure on management and Staff background.

The phenomenon leads to specific consequences grounded on the intensity of causal conditions and strategies. Thus, the consequential Shari'ah compliance is documented.

The model is shown in tabular form below.

\begin{tabular}{|c|c|}
\hline Axial codes & Position on the paradigm model \\
\hline Shari'ah compliance & \multirow[b]{5}{*}{ Causal conditions } \\
\hline Managerial attitude & \\
\hline Customer attitude & \\
\hline Competition with conventional banks & \\
\hline Exploitation of the untapped market & \\
\hline Shari'ah Avoidance & \multirow[b]{4}{*}{ Strategies } \\
\hline Fraudulent Activities/Malpractices & \\
\hline Pressure of management & \\
\hline Staff background & \\
\hline Documented Shari'ah Compliance & Consequences \\
\hline
\end{tabular}

\section{Causal Conditions}

Causal conditions are those incidents which lead to the happening of the phenomena (Strauss and Corbin, 1990). Islamic banks claim that they are Shari'ah compliant, but there are flaws from both customer and 
manager/bank side while implementing Shari'ah. Banks want to exist/survive in the market while some customers wish to earn more profit. So, they both are violating Shari'ah rules for their benefits.

Managers have to accomplish their targets as per instructions. They have less time available to show efficiency or meet their targets, so they rely on skipping some visits or their involvement in some transactions. On the other hand, most of the customers are profit seekers irrespective of banking types. They are also happy because they do not have to put more efforts in completing the tiresome documentation of Islamic banks. The third stakeholder Shari'ah board/mufti is also unable to catch these flaws because the documents are complete as per requirement. So, they restrain the Shari'ah compliance to formal documentation which can't be traced even by the Shari'ah board/Shari'ah audit.

\section{Strategies}

The strategy is the roadmap followed by customers, manager, and management in this process. There are different stakeholders responsible for this misuse of Shari'ah. The customer is involved in Shari'ah avoidance. In some cases, he is not aware of Shari'ah while in more cases he/she is avoiding it intentionally. Banks are unable to control him.

Manager itself is also involved in malpracticing/fraudulent activities because he wants to do his job with ease and comfort while he has to meet the targets too. The conventional background of Islamic banking staff adds more difficulty in exemplary implementation of Shari'ah because they do not know more about Shari'ah and they usually consult senior managers when they face problems. Top management is also stressing the manager to accomplish his/her goals because of they are more interested to please his/her shareholder rather than Shari'ah compliance.

\section{Consequences}

This open code is evolved while going through the analysis of different manager interviews. Shari'ah compliance is defined as, "the set of banking and finance rules implemented according to Islamic law or under the jurisdiction of Islamic law."

Shari'ah compliance is the $\mathrm{x}$-factor of Islamic banking because conventional setup is strong enough to outclass the Islamic banks. Islamic bank attracts customer due to this factor, so the need to follow Shari'ah arises strictly.

Shari'ah compliance Islamic banking is carried out in proper steps and rules are specified for every step/transaction. These steps should be carried out in 
the same manner prescribed by the Shari'ah laws by the manager. This follows up need time and affects their performance regarding fewer transactions done by him/her. Now there is a struggle between his/her goals (targets) and Shari'ah objectives. This creates confusion leading to manipulation of the Shari'ah rules and the confining of the Shari'ah compliance to formal documentation. This scenario can be termed as documented Shari'ah compliance. They skip some steps essential to be followed, and the customer is provided some relaxation for the sake of the transaction fulfillment. These activities cannot be considered illegal or not according to Shari'ah because the formal documents are complete to show in Shari'ah audit or mufti visits.

\section{Positioning the Theory in Literature}

In grounded theory, we go opposite to other traditional research methodologies where a complete literature review is done at the start of the research. The purpose of conducting a literature review at the beginning is to identify and develop essential variables. In this approach, the literature review is done after analysis is completed and theory is developed. The sole purpose is to place the new theory in the literature and check, to what extent the previous research supports it.

In Grounded theory, a comprehensive literature review cannot be done in advance because one cannot decide about the direction of new research. The theory is led by data so one can include from previous literature relevant to the data gathered (Strauss and Corbin, 1990). This literature is used for comparison not for developing a framework. That is why literature review is completed after the theory is generated. This chapter is included to compare the Grounded theory of Shari'ah tagging with existing literature.

\section{Major Issues in Islamic Banking}

The following issues are identified during the research study and after analysis. The previous research has verified the existence of these issues in the following forms. One of the problems facing the Islamic banking is the same documentation for all the Islamic banks and financial institutions in exchange for the Islamic instruments. The apparent reason for these instruments is not standardized could be due to the varying needs of different Islamic banks. For speedy and smooth transactions, the Islamic tools need to be standardized throughout the Islamic banking. There is a lack of public awareness with the different Islamic modes of financing.

The lack of qualified staff that is well versed in the Islamic banking institutions is another hurdle in the advancement of Islamic banking system. 
The supervision of the Islamic banking institutions is subject controversies because it is theoretically under the supervision of the Shari'ah boards, but in practices it is under the control of the professional conventional bankers who are not very much well versed with the Islamic banking.

Most of the Islamic banks have adopted the dual structure in the hope of turning from riba-based on riba-free banking. That is also giving rise to many problems. Many of the Islamic banks in specific countries are working without any legal cover. By legalizing the Shari'ah principles visa-a-visa Islamic banking, the legitimate needs of the Islamic banks can be fulfilled. (Current Issues in the Practice of Islamic Banking by Sayyid Tahir)

\section{Mufti as an Influential Stakeholder}

Research suggests that role of mufti is significant because this person makes the transaction of Islamic banks legal with his/her certification. His presence is too much beneficial for Islamic banks (Baali 2008, Farah, 2008). Shari'ah scholars/mufti grant organizational legitimacy to Islamic banks and without his/her approval Islamic contract is invalid because he/she directs manager from formulation to implementation of Shari'ah compliance (Garas and pierce, 2010). This aspect is discussed in the (section 2.16) of the research study.

\section{Skipping Shari'ah Steps for Ease and Comfort}

Dar (2011) proclaims that the real problem in the implementation and execution of Shari'ah compliance. Formulating Fatwa is an easy task, but the presence of different requirements is necessary. This study also found the existence of a documented Shari'ah compliance discussed in (section 2.23).

\section{Manager's Role in Shari'ah Compliance}

Managers are not willing to implement Shari'ah in the real sense. Their attitude shows that they want the Shari'ah tag for their transactions (Farook and Farook, 2011, Foster, 2009). This issue has been discussed in this study (section 3.2)

\section{Limited Shari'ah Scholars}

The scarcity of Shari'ah scholars is found in the literature as one of the big problems faced by Islamic banks (Farook and Farook, 2011). The role of Shari'ah scholar/mufti is like an ISO standard because they are the only being that can stop managers from manipulating Shari'ah. If their bank visits are less than a manager will be free for mall practicing. This aspect is discussed in this study (section 2.16, 2.11). It can be the bank strategy to avoid strict Shari'ah supervision as found in the previous literature (Wright, 2006). 


\section{Lack of Expert Shari'ah Scholars}

A considerable extent of writings shows that Islamic scholars have lack of expertise in the banking sector (Farook and Farook, 2011, Karim and Archer, 2007, El Tiby, 2011, Grais and Pellegrini, 2006, Grais and Pellegrini, 2006a, Ghoul, 2008). This option makes the manager's life easier because they are free to do according to their way. Farook and Farook (2011) and (EL-Gamal, 2006) agree to equip the Shari'ah scholars with formal banking education so they may know the intricacies of banking to avoid manager from malpracticing. This study concurs with this literature, and this issue is presented in (section 3.3 and 3.5).

\section{Findings, Conclusion, and Recommendations}

Islamic banks operate under the rules of Shari'ah. They have additional employees, i.e., Shari'ah scholars along with the management team. These Shari'ah scholars help management in Shari'ah issues and provide Shari'ah certification for Islamic banking products, while the management team deals with the customers. Stakeholders are also responsible for Shari'ah compliance because of their ethical and legal responsibilities their stakeholders. This research study reveals that Shari'ah implementation in the market is confined to the extent of documents. The core category in this study, i.e., Shari'ah Tagging explains this situation. The form of malpractice starts when three of the stakeholders, especially manager and customer pursue their goals. The manager is bound by top management to achieve a specific target in a particular time limit while the customer is seeking profit being a market player.

Islamic banks deal with different types of customers. The first category includes that customer having a religious belief with less knowledge of Islamic banking. The second category forms customer who has left conventional banking for the sake of Islamic banking and third the market players or business figures who want to earn maximum profits. All of these customers want to get profits. The manager has to deal with them and retain them for future transactions.

There are some significant causal conditions which lead the scholar to the phenomena, i.e., managerial attitude, customer attitude, exploitation of the untapped market and competition with conventional banks. These are the factors compelling the parties to violate Shari'ah rules. These conditions show us the extent of involvement of every person in this malpractice.

Customer and manager are using some strategies to help them in this malpracticing. Those strategies are Shari'ah avoidance, fraudulent activities/ 
malpracticing, staff background and pressure of management. In the light of the strategy used by the manager and customer, it is impossible to achieve Shari'ah compliance in actuality.

\section{"Put less Pressure on Manager"}

The manager is one of the critical pillars of Islamic bank executing the Shari'ah rules practically. He/she is given targets to meet at a specific time, and this will decide his/her performance and remuneration. This task is assigned from the upper management.

The problem lies where the manager is under the pressure to perform a task, then he is not capable of completing the long process Islamic banking transactions. He will merely skip some steps and will go forward with the operation to achieve his/her quota.

Islamic banks should put less pressure on the manager to ensure the implementation of Shari'ah practically. The manager performance should not be linked with transactions because being Islamic banks, they should differentiate themselves from conventional procedures and carry on with exact Shari'ah rules.

Manager relaxation can lead us to exact Shari'ah implementation, and the bank should adopt this strategy. Banks may use some other ways to regulate the manager.

\section{"Employee Training and Development"}

Most of the Islamic banks and specifically the Islamic windows of conventional banks should train their employees. The employees having a Conventional background are assigned to serve in Islamic windows while they do not have even the basic knowledge. If they are aware of the Islamic banking practices and the rules implemented there, the implementation of Shari'ah will be ensured.

\section{"Ensure Frequent Shari'ah Audits"}

When the Shari'ah members do not visit a bank for Shari'ah audit, then the managers feel good. They are free to do whatever. Islamic banks need to increase the frequency of Shari'ah Audits, in this way Shari'ahh implementation can be ensured.

\section{"Increase the Number of Shari'ah Auditors"}

Islamic banks face the scarcity problem of Shari'a Auditors. There are more banks to visit for a single Shari'ah Auditor. According to a manager, a single 
Shari'ah Auditor has to visit 120 branches. It is not feasible, so there is an intense need to increase their quantity to ensure Shari'ah implementation.

\section{"Customer Awareness"}

Islamic banking customers have faith in Shari'ah-compliant banking, but they are unaware of Islamic banking procedures. Islamic bank should launch feasible campaigns to educate their customers regarding Shari'ah.

\section{"Avoid Profit Seekers"}

Market players who come with a motive to earn more profit should be discouraged to ensure the sanctity if Shari'ah. The dirty fishes should be thrown out of the Islamic banking compound.

\section{References}

Agha, O. (2012). Is Islamic Finance a Failure? An Assessment, Fri Jan, 27(2012), 1.

Ahmad, A., Ur Rehman, K., \& Saif, M.I. (2010). Islamic banking experience of Pakistan: comparison between Islamic and conventional banks. International Journal of Business and management, 5(2), 137.

Al Sharif, M. (2008). Shari'a supervision over banks and Islamic Financial Institutions. In Third Global Conference on Islamic Economy, Umm Al Qora University, Saudi Arabia.

Baali, A. (2008). The effective Shari'a supervision in Islamic Financial Institutions. In Third Global Conference for Islamic Economy Umm Al Qora University, Saudi Arabia.

Berger, P.L., \& Luckmann, T. (1967). The Social Construction of Reality: A Treatise in the Sociology of Knowledmann. Anchor Books.

Charmaz, K. (2006). Constructing Grounded Theory. Qualitative Research in Organizations and Management: An International Journal, 2(2), 84103.

Crotty, M. (1998). The foundations of social research: Meaning and perspective in the research process. Sage.

Dar, H. (2011). Importance of Shari'a audit for conventional banks offering Islamic financial products. Business in Asia.

Dar, H.A., \& Presley, J.R. (2000). Lack of profit loss sharing in Islamic banking: management and control imbalances. International Journal of Islamic financial services, 2(2), 3-18.

Donna M. Mertens. (1998). Research methods in education and psychology: integrating diversity with quantitative \& qualitative approaches. Sage Publications.

El-Gamal, M.A. (2005). Limits and dangers of Shari'a arbitrage. Islamic Finance: Current Legal and Regulatory Issues, 117-132. 
Farah, F. (2008). Shari'a supervision: Model and reality. In Third Global Conference on Islamic Economy, Umm Al Qora University, Saudi Arabia.

Farook, S.Z., \& Farooq, M.O. (2011). Shari'ahh governance for Islamic finance: Challenges and pragmatic solutions. Available at SSRN, 1813483.

Merchant, I. P. (2012). An empirical study of Islamic banks versus conventional banks of GCC. Global Journal of Management and Business Research, 12(20).

GARAS, S. N. \& PIERCE, C. 2010. Shari'ah supervision of Islamic financial institutions. Journal of Financial Regulation and Compliance, $18,386-407$.

Glaser, B.G., Strauss, A.L., \& Strutzel, E. (1968). The discovery of grounded theory; strategies for qualitative research. Nursing Research, 17(4), 364.

Glase, B.G., \& Strauss, A.L. (1967). The discovery of grounded theory: Strategies for qualitative research. New York: Aldlne.

Glaser, B.G. (1998). Doing grounded theory: Issues and discussions. Sociology Press.

Hussein, K., \& Omran, M. (2005). Ethical investment revisited: evidence from Dow Jones Islamic Indexes. The Journal of Investing, 14(3), 105126.

Iqbal, M., Molyneux, P., \& Conermann, S. (2006). Thirty years of Islamic banking. History, Performance, and Prospects. Bankhistorisches Archiv, 32(2), 155-158.

Kahf, M. (2004). Islamic banks: the rise of a new power alliance of wealth and Shari'a scholarship. The politics of Islamic finance, 17-36.

Kuran, T., Benthall, J., \& Maurer, B. (2001). Speculations on Islamic financial alternatives. Anthropology today, 17(3), 28-29.

LAWAI, H. (1994). The role of Shari'ah'h Council in developing banking products. In Islamic Banking and Finance Conference, Dubai, November (pp. 6-7).

Lee, K.H., \& Ullah, S. (2008). Inter-bank cooperation between Islamic and conventional-the case of Pakistan. International Review of Business Research Papers, 4(4), 1-26.

Lincoln, Y.S., Lynham, S.A., \& Guba, E.G. (2011). Paradigmatic controversies, contradictions, and emerging confluences revisited. The Sage handbook of qualitative research, 4, 97-128.

Newman, I., \& Benz, C.R. (1998). Qualitative-quantitative research methodology: Exploring the interactive continuum. SIU Press.

Neuman, W.L. (2013). Social research methods: Qualitative and quantitative approaches. Pearson education. 
Strauss, A., \& Corbin, J. M. (1990). Basics of qualitative research: Grounded theory procedures and techniques. Sage Publications, Inc.

Strauss, A., \& Corbin, J. M. (1990). Basics of qualitative research: Grounded theory procedures and techniques. Sage Publications, Inc.

Schwandt, T.A. (200i). Dictionary of qualitative inquiry (3rd Ed.). Thousand Oaks, CA: Sage.

Singh, H. (2009). The absence of Shari'a audit a serious loophole. The Malaysian Reserve.

SunGard. (2008). Islamic Banking and Finance-Growth and Challenges Ahead. www.sungard.com

Wilson, R. (1999). Challenges and opportunities for Islamic banking and finance in the West: The United Kingdom experience. Thunderbird International Business Review, 41(4-5), 421-444. 